\title{
SNOW SURFACE ELEVATION IN THE FILCHNER ICE SHELF AREA, ANTARCTICA
}

\author{
By John C. BEHREndT \\ (U.S. Geological Survey, Denver, Colorado, U.S.A.)
}

\begin{abstract}
Altimeter observations made on flights during the austral summer ${ }_{9} 63_{3}-64$ in the vicinity of the Filchner Ice Shelf have allowed the construction of a new topographic map of the snow surface in that area. The ice stream flowing into the ice shelf from the polar plateau is more clearly defined. A previously shown connection from Berkner Island to the grounded ice to the west-south-west appears not to exist. The mass flux from the drainage basin on the polar plateau can be accounted for by a reasonable ice-shelf flow rate. The area of the ice shelf shown on the map is $0.43 \times 10^{6} \mathrm{~km}^{2}$.
\end{abstract}

RÉsumé. Altitude de la surface de la neige dans la région du Filchner Ice Shelf, Antarctique. Des observations altimétriques faites au cours de vols pendant l'été austral ${ }_{9} 6_{3}-64$ dans la région du Filchner Ice Shelf ont permis la construction d'une nouvelle carte topographique de la surface de la neige. Le fleuve de glace qui se jette dans le ice shelf à partir du plateau polaire est défini plus clairement. La connexion déjà signalée de Berkner Island à la glace reposant sur le fond vers le ouest-sud-ouest n'existe pas. Le flux de masse du bassin de drainage du plateau polaire peut être estimé par une vitesse d'écoulement raisonnable de l'ice shelf. La surface de l'ice shelf de la carte est de $0,43 \times 10^{6} \mathrm{~km}^{2}$.

Zusammenfassung. Die Höhe der Schneeoberfläche im Gebiet des Fïlchner Ice Shelf, Antarktis. Radar-AltimeterBeobachtungen bei Flügen in der Umgebung des Filchner Ice Shelf während des Süd-Sommers I $963 / 64$ ermöglichten die Zeichnung einer neuen topographischen Karte der Schneeoberfläche in diesem Gebiet. Der Eisstrom, der dem Eisschelf aus dem Pol-Plateau zufliesst, wurde schärfer erfasst. Eine früher angenommene Verbindung zwischen dem Berkner Island und dem auf dem Untergrund aufsitzenden Eis im WestSüdwesten scheint nicht zu bestehen. Der Massenzufluss aus dem Einzugsgebiet am Pol-Plateau kann durch eine vernünftige Fliessgeschwindigkeit des Schelfeises kompensiert werden. Auf der Karte ist ein Gebiet von $430000 \mathrm{~km}^{2}$ des Eisschelfes dargestellt.

\section{INTRODUCTION}

During the austral summer of $1963-64$, personnel of the University of Wisconsin carried out a program of aeromagnetic observations in Antarctica (Behrendt, ig64[b]). In the course of this work barometric and radio-altimeter observations were made at approximately $15 \mathrm{~km}$. intervals, or closer over steep surface slopes, which enabled calculation of snow surface elevation along the flight lines. The radio-altimeter used operated at $4,300 \mathrm{Mc}$./sec. so snow penetration was negligible. Oversnow traverse tracks were used as control where crossed. As several of these flights were in the relatively little known Filchner Ice Shelf area they enabled an improved surface elevation map to be drawn.

Data from the following oversnow traverses in the area were also used: Sentinel traverse, 1957-58 (Bentley and Ostenso, I96r), Ellsworth-"Byrd" traverse, I958-59 (personal communication from E. A. Bradley), Filchner Ice Shelf traverse, I 957-58 (Behrendt, I 962[b]), Commonwealth Trans-Antarctic Expedition, 1957-58 (Pratt, I960), Ellsworth Highland traverse, I960-6I (personal communication from C. R. Bentley), Antarctic Peninsula traverse, I96I-62 (Behrendt, I964[a], "Byrd"-Pole traverse, I960-6r (personal communication from F. L. Dowling) and the i $963-64$ "Byrd station" traverse (personal communication from M. Hochstein). In addition surface elevation data were used from the $1960-61$ aeromagnetic flights (Behrendt and Wold, I963). The oversnow traverse elevations are accurate for the most part to $\pm 5^{\circ} \mathrm{m}$. The adjusted elevations along the flight lines are believed accurate to about $\pm \mathrm{I} O \mathrm{~m}$., although they are probably better over the ice shelf itself.

\section{Discussion}

Figure $\mathrm{I}$ is the snow surface elevation map. Several features shown warrant some discussion. The ice stream draining a large part of the polar plateau is indicated by the contours in the area south of lat. $85^{\circ} \mathrm{S}$. between long. $60^{\circ}$ and $100^{\circ} \mathrm{W}$. These contours are not as steep in one location as those shown by Behrendt and others (1962). An error was found in one of the flight lines used in that map; these data were not used here. 


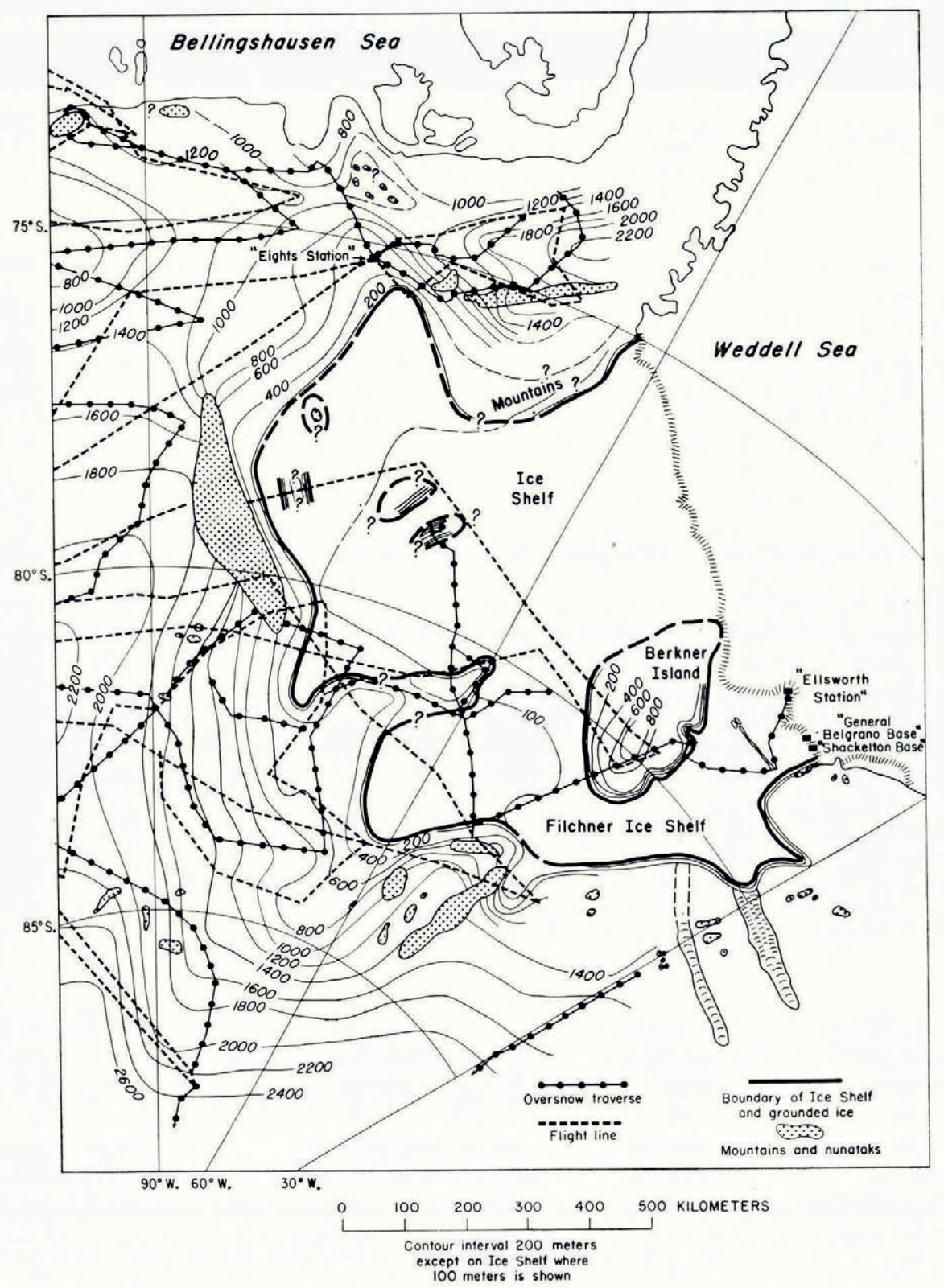

Fig. 1. Snow surface elevation map of the Filchner Ice Shelf area of Antarctica. Elevation data are spaced for the most part at about $6 \mathrm{~km}$. intervals on oversnow traverses and at about $15 \mathrm{~km}$. on fight lines

Behrendt ( $1962[\mathrm{a}]$ ) postulated the existence of this ice stream on the basis of the mass discharge of the Filchner Ice Shelf, and calculated that about $100 \times 10^{15} \mathrm{~g} \cdot \mathrm{yr}^{-1}$ of mass flowed out of the section of the ice front between Berkner Island and the coast to the east. Giovinetto (1964), in a discussion of the ice drainage basins of Antarctica, calculated that the mass output in the eastern part of the Filchner Ice Shelf drainage system should amount to 
about $200 \times \mathrm{IO}^{15} \mathrm{~g}$. yr. ${ }^{-1}$ from a determination of the mass input in the entire system. The difference of $100 \times 10^{15} \mathrm{~g}$. $\mathrm{yr}^{-1}$ was greater than the observational errors would allow, even neglecting bottom melting beneath the ice shelf. Both authors assumed that the bulk of the drainage from the polar plateau was through the section east of Berkner Island, based on the map of the Filchner Ice Shelf available following the 1957-58 Filchner Ice Shelf traverse (Neuburg and others, I959). This traverse party, of which the author was a member, projected the grounded ice feature crossed at about lat. $80^{\circ} 30^{\prime} \mathrm{S}$., long. $62^{\circ} \mathrm{W}$. north-eastward to connect with Berkner Island. Two parts of one of the flights shown in Figure I crossed the ice shelf in this area and showed no evidence of a grounded ice connection. This being the case, it is clear that a large part of the ice entering from the polar plateau is flowing through this section.

A simple calculation was made to determine whether the discrepancy of $100 \times \mathrm{IO}^{15} \mathrm{~g} . \mathrm{yr} .^{-1}$ noted by Giovinetto (1964) could be explained. The distance between Berkner Island and the grounded ice feature to the west-south-west is about $160 \mathrm{~km}$. as shown in Figure $I$. Behrendt ( $\mathrm{I}_{962}[\mathrm{a}]$ ) showed an ice thickness of $500 \mathrm{~m}$. for this part of the ice shelf. The product of these quantities gives the cross-sectional area of the ice flowing through this section, $8 \times \mathrm{IO}^{\mathrm{II}} \mathrm{cm}^{2}$. Since the error estimate cited by Giovinetto is $\pm 57 \times \mathrm{IO}^{15} \mathrm{~g}$. yr. ${ }^{-1}$, the velocity of ice-shelf flow required through this section is obtained by dividing the cross-sectional area into the mass flux difference, viz. $1 \cdot 25 \pm 0 \cdot 7 \mathrm{I} \times 10^{5} \mathrm{~cm} . \mathrm{yr}^{-1}$ or $\mathrm{I} \cdot 25 \pm 0 \cdot 7 \mathrm{I} \mathrm{km} . \mathrm{yr}^{-1}$. This is a reasonable figure and thus the discrepancy can be accounted for.

In Figure $\mathrm{I}$ the line indicating the boundary of the grounded ice connects the feature west-south-west of Berkner Island to the higher ice farther west. This was done because surface observations made by the author and other members of the Filchner Ice Shelf traverse party showed that the grounded ice contact in the vicinity of this feature was at an elevation of about I Io m. This contrast with the $200 \mathrm{~m}$. contour border of the ice shelf in other areas is probably the result of the fairly shallow depth to bedrock in the area where this grounded feature was crossed (Behrendt, I962[a]) relative to the parts of the area where the $200 \mathrm{~m}$. contour defines the boundary.

The western area of the ice shelf is still relatively unknown and several islands other than those shown could exist. The precise locations and configurations of these are uncertain as they were only seen from the air, with the exception of the one reached by the Filchner Ice Shelf traverse. The position of the flight line shown in the area of these islands is possibly somewhat in error.

It is likely that the boundary of the ice shelf in the vicinity of lat. $77^{\circ} \mathrm{S}$., long. $70^{\circ} \mathrm{W}$. may actually be farther to the north and that the mountains(?) in this area may be the same as those studied by the Antarctic Peninsula traverse (Behrendt, 1963) in the vicinity of lat. $75^{\circ} \mathrm{S}$., long. $70^{\circ} \mathrm{W}$. On the flight shown in the latter area, I observed no rock exposures south of those shown and the snow surface appeared to descend continuously to the south. Visual observations on this same flight also showed the apparent ice shelf boundary south of "Eights station" where elevations of less than $200 \mathrm{~m}$. were measured.

The area of ice shelf shown in Figure I is $0.43 \times \mathrm{IO}^{6} \mathrm{~km}^{2}$, not including the islands, which compares with $0.39 \times 10^{6} \mathrm{~km} .^{2}$ from Thiel (I 962$), 0 \cdot 355 \times 10^{6} \mathrm{~km} .^{2}$ from Suyetova (1963) and $0.50 \times 10^{6} \mathrm{~km}^{2}$ from Giovinetto (unpublished). Giovinetto's value was based on evidence from the Antarctic Peninsula traverse and probably is in agreement with the value obtained from Figure I within the experimental error, although it appears somewhat high. Thiel's and Suyetova's values are too low and reflect the maps prior to the discovery of the extension of the ice shelf into the area immediately south of "Eights station" as discussed by Giovinetto and Behrendt ( 1964 ). The area could be increased to as much as $0.48 \times 10^{6} \mathrm{~km}^{2}$ if the north-western border approaches the mountains mapped by the Antarctic Peninsula traverse as discussed above. These values are comparable to the somewhat larger Ross Ice Shelf of $0.54 \times 10^{6} \mathrm{~km} .^{2}$ (Giovinetto, 1964 ). 


\section{ACKNOWLEDGEMENTS}

Richard Wanous and Per Gjelsvik deserve thanks for collecting the altimeter data in conjunction with their aeromagnetic work. Air Development Squadron 6 (VX6), U.S. Navy, provided the air support for this program. The field work was supported by a grant from the National Science Foundation to the University of Wisconsin and was carried out while the author was employed at that institution.

MS. received I January 1965

\section{REFERENCES}

Behrendt, J. C. $1962[\mathrm{a}]$. Geophysical and glaciological studies in the Filchner Ice Shelf area of Antarctica. Fournal of Geophysical Research, Vol. 67, No. I, p. 22 I-34.

Behrendt, J. C. $1962[\mathrm{~b}]$. Summary and discussion of the geophysical and glaciological work in the Filchner Ice Shelf area of Antarctica. University of Wisconsin. Geophysical and Polar Research Center, Report 62-3.

Behrendt, J. C. 1963 . Seismic measurements on the ice sheet of the Antarctic Peninsula. Fournal of Geophysical Research, Vol. 68, No. 21, p. 5973-90.

Behrendt, J. C. I964[a]. Antarctic Peninsula traverse geophysical results relating to glaciological and geological studies. University of Wisconsin. Geophysical and Polar Research Center, Report 64-1.

Behrendt, J. C. 1964 [b]. Distribution of narrow width magnetic anomalies in Antarctica. Science, Vol. I44, No. 362, p. $993-94$.

Behrendt, J. C., and Wold, R. J. 1963. Aeromagnetic survey in West Antarctica 1963. University of Wisconsin. Geophysical and Polar Research Center, Report 63-1.

Behrendt, J. C., and others. I 962 . Ice surface elevation of central Marie Byrd Land, by J. C. Behrendt, R. J. Wold and F. L. Dowling. Journal of Glaciology, Vol. 4, No. 31, p. $121-23$.

Bentley, C. R., and Ostenso, N. A. 1961. Glacial and subglacial topography of West Antarctica. Fournal of Glaciology, Vol. 3, No. 29, p. 882-911.

Giovinetto, M. B. 1964. The drainage systems of Antarctica: accumulation. (In Mellor, M., ed. Antarctic snore and ice studies. Washington, D.C., American Geophysical Union, p. 127-55. (Antarctic Research Series, Vol. 2.))

Giovinetto, M. B. Unpublished. Preliminary report on drainage systems of Antarctica. [Paper presented at the Karlsruhe meeting of the Deutsche Gesellschaft für Polarforschung, October 1963.]

Giovinetto, M. B., and Behrendt, J. C. 1964. The area of ice shelves in Antarctica. Polar Record, Vol. 12, No. 77, p. $171-73$.

Neuburg, H. A. C., and others. 1959. The Filchner Ice Shelf, by H. A. C. Neuburg, E. Thiel, P. T. Walker, J. C. Behrendt and N. B. Aughenbaugh. Annals of the Association of American Geographers, Vol. 49, No, 2 , p. I $10-19$.

Pratt, J. G. D. I960. A gravity traverse of Antarctica. Trans-Antarctic Expedition, 1955-1958. Scientific Reports, No. 2.

Suyetova, I. A. I963. The area of Antarctica and of its major ice shelves. Polar Record, Vol. I I, No. 75 , p. 735.

Thiel, E. 1962. The amount of ice on planet Earth. American Geophysical Union. Geophysical Monograph No. 7 , p. $172-75$. 